\title{
Selected Reference Books of 1993-1994
}

\section{Eileen McIlvaine}

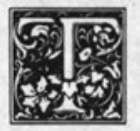

his article follows the pattern set by the semiannual series initiated by the late Constance M. Winchell more than forty years ago and continued by Eugene Sheehy. Because the purpose of the list is to present a selection of recent scholarly and general works of interest to reference workers in university libraries, it does not pretend to be either wellbalanced or comprehensive. A brief roundup of new editions of standard works is provided at the end of the articles. Code numbers (such as AD540 and 1CJ331) have been used to refer to titles in the Guide to Reference Books (10th ed., Chicago: ALA, 1986) and the Supplement . . Covering Materials from 1985-1990 (Chicago: 1992).

\section{DICTIONARIES}

Lewis, Ivor. Sahibs, Nabobs, and Boxwallahs: A Dictionary of the Words of AngloIndia. Bombay and New York: Oxford Univ. Pr., 1991. 266p. Rs395 (ISBN 019-562582-X). LC 91-900834.

In the latter half of the nineteenth century two Englishmen, Henry Yule and A. C. Burnell, who had served the government of India, collaborated to produce a masterpiece of scholarship entitled $\mathrm{Hob}$ son-Jobson: A Glossary of Colloquial AngloIndian Words and Phrases, and of Kindred Terms, Etymological, Historical, Geographical and Discursive (1903. AD128).

The present work attempts to fill "certain lacunae in Hobson-Jobson in order to achieve a better balance between the words of the common sort and those in the learned registers of theology, indology, philosophy and the like"-Pref. Many of the newly added words were culled from pages of historical dictionaries, especially The Oxford English Dictionary and its predecessor The New English Dictionary, which were, for the most part, compiled after the publication of Hobson-Jobson.

Salibs, Nabobs and Boxwallahs (AngloIndian words signifying roughly, lords, government deputies, and businessmen respectively) contains significantly fewer words, has less wordy, and consequently less exhaustive, definitions and etymological comments, and only cites references, not actual quotations, illustrating word usage. Its virtue lies in the fact that in spite of its conciseness, it is comprehensive and scholarly. Moreover it includes many common words, some of which originated in the twentieth century, and could not have been included in Hobson-Jobson.-O.d.C.

\section{DATABASES}

Bazy Dannykh Rossii: Katalog 2,500 Baz Dannykh po vsem Oblastiam deiatel'nosti. [Russian Databases: ACatalog of 2,500 Databases in all Areas of Activity] Moskva: NTTS “Informregistr," 1993. Various pagings.

Bazy Dannykh Rossii is a publication of the Committee on Computerized Information of the Russian Republic, which acts as a clearinghouse for information on publicly available computerized databases. Its research center, "Informregister," maintains a database of descriptive entries-now numbering some 10,000 from which the entries in this publication are drawn. Though not easy to

Eileen Mclloaine is Head of Reference and Collections, Butler Library, Columbia University, New York, NY 10027. Although it appears under a byline, this list is a project of the reference departments of Columbia University Libraries, and notes are signed with the initials of one of the following staff members: Paula Gabbard, Katherine A. Keller, Avery Library; James L. Coen, Business Library; Mary Cargill, Olla della Cava, Robert H. Scott, Sarah Spurgin, Junko Stuveras, Butler Library: Elizabeth Davis, Music Library. 
decipher (the technical jargon and acronyms presented some difficulty to this non-Russian), this Russian-language database directory nevertheless gives some insight into the burgeoning information industry in Russia. Focusing on Russian databases (the two previous editions-1990 and 1991-were broader in scope), this edition lists 2,500 entries and features several indexes.

The entries appear according to a classified subject arrangement that is roughly outlined in the table of contents. In addition each entry bears a numeric subject code from a separately published technical information thesaurus, the Gosudarstvennoi rubrikator nauchnotekhnicheskoi informatsii (4th ed. Moscow: VINITI, 1992). Constructed on the basis of information submitted by the database producers, the entries indicate the name of the database, give a brief description of the contents, mention the type of documents, the language, and the dates covered, and give technical information regarding computer requirements.

Bazy Dannykh Rossii attempts to be comprehensive. Both governmental and private database producers' products are listed, all regions of the country are represented, all types of databases-bibliographic, indexing and abstracting, numerical, full-text-are included, and, although business and scientific databases predominate, social science and humanities databases can also be found.

There is an alphabetical subject index and an index of database producers giving address, telephone number, and their respective database products. However, there is no index to the databases by name.-O.d.C.

\section{RELIGION}

Caldwell, Sandra M., and Ronald J. Caldwell. The History of the Episcopal Church in America, 1607-1991: A Bibliography. Religious Information Systems, 15. New York: Garland, 1993. 528p. \$82 (ISBN 0-8153-0936-8). LC 92-45272.

This bibliography of secondary works lists some 3,800 books, articles, and dissertations on the history of the Episcopal
Church in America. General sections of reference works, general histories, period histories, topical works, and biographies are further subdivided by subject. The largest section, and probably the most useful, lists 1,600 local histories by state and town, including the histories and guides to archives of many individual churches. The topical sections, addressing African Americans, women, music, Anglo-Catholicism, architecture, education, etc., are very useful, although the section on education does not seem to have a clear focus. It lists histories of a few of the schools and colleges that were founded by the Episcopal Church, but omits many others. The topical arrangement with an author index works fairly well, though interesting studies of evangelicalism, marriage, and Native Americans are buried in the "miscellaneous" section, where the absence of a subject index is most keenly felt. Despite these limitations, there is no other comparable bibliography on the history of the Episcopal Church in America, making this a valuable reference work for American and church history.-S.S.

\section{LITERATURE}

Weekes, Ann Owens. Unveiling Treasures:

The Attic Guide to the Published Works of

Irish Women Literary Writers. Dublin:

Attic Pr., 1993. 368p. £28.99, \$47 (ISBN 1-85594-0728).

Unveiling Treasures includes nearly 250 Irish women writers of drama, fiction, and poetry, ranging from Mary Davys (1674-1732) to such contemporary writers as Nuala $\mathrm{Ni}$ Dhomhnaill (born 1955). In each entry a biographical profile and discussion of the work, often quoting the author, is followed by a list of writings. The compiler's aim has been "to collect rather than evaluate; thus it is inclusive with respect to writers' work and to details of nationality"-Introd. Many of the entries for contemporary writers are based on personal communication or taken from their books and consequently do not provide many biographical facts, other than year of birth, place of birth, general education, and current domicile. Occasionally the en- 
tries will note that the author is married or has children, but names of husbands or children seem to have been excluded on principle (the entry for Lady Wilde never mentions her son Oscar Wilde). Writers living anywhere in Ireland are included, together with many Irish authors living elsewhere. The entries are generally longer than those found in $A$ Biographical Dictionary of Irish Writers (Suppl. 1 BD271) and include far more women writers, as well as more complete lists of works.-S.S.

\section{MUSIC}

Encyclopedia of Recorded Sound in the United States. Guy A. Marco, editor; Frank Andrews, contributing editor. Garland Reference Library of the $\mathrm{Hu}$ manities, 936. New York and London: Garland, 1993. 910p. \$125 (ISBN 07190-3492-2). LC 93-18166.

Since 1877, when Thomas Edison invented the tinfoil phonograph and inaugurated the recording of sound, the recording of music and nonmusical sounds has become a permanent fixture in our lives. This encyclopedia provides a compendium of information on the first one hundred years of this activity. The approximately three thousand entries have been written primarily by Guy Marco. Also included are another three dozen signed articles whose contributors are identified, with their articles, at the beginning of the volume.

The arrangement of the entries is alphabetic. All headings, with cross-references, are listed before the text, making it easy to scan. The chronological period covered is roughly 1877 to 1970 . However, some later entries important to the topic are included, such as those on the compact disc, and the extension into rap performers in the article on "Sexually oriented lyrics." The main focus is on developments in America, but international subjects are also included.

Because the field covered is a technological medium featuring a variety of topics, the content of the entries runs the gamut from engineering techniques and recording studios to performers, music genres, etc. The reader will find a defini- tion for the "ping pong effect" (a stereophonic separation of signals); an entry for "Trevor Pinnock" (contemporary English harpsichordist important in the Early Music movement and a winner of several recording awards); an extensive bibliography of sound recordings periodicals; a description of the Salon du Phonographe in Paris, perhaps the earliest record library; and a concise summary of the present state of the "Preservation of sound recordings," among others.

An extensive bibliography (pp. 787824), compiled from the articles and keyed to them, and a detailed index close the work. This encyclopedia provides a reference work in an area yet to be heavily covered by the scholarly literature and does so in an intelligently organized and informative way.-E.D.

\section{DANCE}

Bopp, Mary S. Research in Dance: A Guide to Resources. New York: G. K. Hall, 1994. 296p. \$50 (ISBN 0-8161-9065-8). LC 92-42508.

This welcome and long-needed guide is divided into two parts, the first listing sources for dance material and the second listing printed resources. The meat of the first section is a list of libraries and archives including many non-U.S. institutions. Each entry, compiled through questionnaires and, in some cases, site visits, includes a brief description of the collection, any specialized finding aids, and information about circulation policies. This section is completed by a convenient list of dance publishers, specialized bookstores, and dance organizations.

The section on printed sources is a topically arranged, annotated bibliography of reference works, including many sources on ethnic dances. It also lists alphabetically some two hundred, mainly English-language, dance periodicals available as of 1992 for all kinds of dance, ballroom, folk, classical, etc.

Any library with an interest in the arts, popular culture, or ethnic studies should find this work very useful.-M.C.

International Dictionary of Ballet. Ed. Martha Bremser. Detroit: St James Pr., 
1993. 2 vols. $\$ 230$ (ISBN 1-55862-0842). LC 93-25051.

Since Selma-Jeanne Cohen's longawaited international dictionary of dance appears to be on hold, this work is a must-buy for any library with an interest in the arts. Like the other St James encyclopedias, it has many virtues. The well-written entries deal primarily with individuals and specific ballets and provide essential information (including lists of major roles and their dates), generally well-balanced essays, and references to other sources. Unfortunately, the work is stronger on details than on overviews; individual ballet companies are listed but not general periods. A student needing a brief explanation of the Romantic ballet will find nothing, not even cross-references to the informative entries on Gautier, $\mathrm{L} a$ Sylphide, Cerrito, Giselle, and many others. Nor are terms defined; nothing on the development of the tutu, the point shoe, or ballet technique.

There is a slight British and European bias in the choice of dancers and ballets. Nijinska's La Valse is the main entry, while Balanchine's version gets a paragraph; some young British dancers getentries but not their American counterparts.

It is lavishly illustrated, and the photographs are generally well-chosen though not always well-documented-dates, and sometimes roles, are not uniformly provided. But these are quibbles, and this is a welcome resource for the useful information it does provide.-M.C.

\section{ART AND ARCHITECTURE}

Spanish Artists from the Fourth to the Twentieth Century: A Critical Dictionary. Frick Art Reference Library, New York. New York: G. K. Hall, 1993. Vol. 1 (to be in 3 vols.). \$420 (ISBN 0-81610614-2).

Readers of this dictionary might at first be disappointed that biographical information is limited. But once the reader finds out that this dictionary of 7,000 artists' names grew out of the Frick Art Reference Library's name-authority file of Spanish artists drawn from its photograph archive, it becomes clear that the dictionary far surpasses any standard for a name-authority file. By adding bibliographic citations after every name listed, it fills a serious gap in the bibliographic world.

The acknowledged precedent for Spanish Artists is the privately printed Catalogue of Painters and Draughtsmen Represented in the Library of Reproductions of Pictures \& Drawings Formed by Robert and Mary Witt (London, 1920). But unlike the Witt's Catalogue, the Frick's Spanish Artists offers more than just an alphabetical list of artists with basic information transferred from the captions and annotations accompanying the photographs. Spanish Artists includes the artist's dates and medium (if not a painter), variant names of the artist $(90,000$ names are listed), national school (if significant), and a brief bibliography. Variant forms of the artist's name immediately follow the preferred entry, and each entry ends with bibliographic references where further information on the artist can be found. Cross-references from variant forms to the preferred form of each artist's name are particularly critical in sorting out compound Spanish surnames.

Spanish Artists begins with an introduction that describes both the inspiration for this publication and the historical foundation for such a publication at the Frick. A guide to use written in English, Spanish, French, and German follows.

At the time of this review, only volume 1 has been published. At the end of the last volume (vol. 3) there will be a chronological list of all the artists listed and a complete bibliography of sources used in the compilation of information on each artist. The end of volume 1 already has the complete alphabetical list of cross-references that refer to the established entries that fall within the first volume (artists names from $A$ to $F$ ), as well as a bibliography of all sources cited in volume 1 . The bibliography for the volume is quite large (50 pages and approximately 1,400 citations). The complete bibliography at the end of the final volume will in itself be a significant contribution to the scholarship on Spanish art. 
Although this work may not fulfill every desire for an authoritative biographical dictionary of Spanish artists, it goes much further than any other currently available source in providing authoritative bibliographical and basic biographical information for Spanish artists.-P.G.

Storrer, William Allin. A Frank Lloyd Wright Companion. Chicago: Univ. of Chicago Pr., 1993. 492p. \$75 (ISBN 0226-77624-7). LC 93-30127.

The stated purpose of this work is to be a companion, not an encyclopedia, and it lives up to this purpose by documenting in plans, black-and-white photographs, drawings, and commentary, Frank Lloyd Wright's nearly 500 known works built from over 20,000 drawings, including about 100 structures that have been destroyed. In addition to identifying each built structure designed by Frank Lloyd Wright or under his direction, the author places the work within a context by client, by the time and/or place of the design's conception or construction, or by a combination of these.

The six-page preface provides information essential to understanding Storrer's approach and presentation of material. Most important to note is that the work features as-built plans and photographs that abide by Wright's rules of composition. The author of The Architecture of Frank Lloyd Wright: A Complete Catalog (Cambridge: MIT Pr., 1974), Mr. Storrer knows his subject and refers to other books on Wright such as HenryRussell Hitchcock's In the Nature of $\mathrm{Ma}$ terials (New York: Duell, 1942) and the 12-volume Frank Lloyd Wright (Tokyo: A.D.A. Edita, 1984-1988) by the Taliesin archivist, Bruce Brooks Pfeiffer, in order to explain how this book is different.

Arranged chronologically, each entry includes the basic facts of the building, including the following: the author's unique catalog number (Storrer number); a project number (T. or Taliesin number); an identifying name (with the parts necessary for unique identification in boldface type); the date the project first took a form fully identifiable in the final built work; the location of the project by city and state; and notes on the current status of the original work. Due to the difficulty for some in "reading" plans, plans are not only shown but also described in most entries. As mentioned above, the contextual content of each entry is what makes this work unique. Information on visiting these buildings (where possible) is also included.

Entries are interspersed with eight short essays on different phases or aspects of Wright's work, with titles such as, "Transition from Prairie to Usonia," "Historical Overview of Frank Lloyd Wright's Career," and 18 one-page sets of plans and text with titles such as, "Prairie Vocabulary," and "Basics of Early Wright Design." There are some references to these essays within the entries and some essays and plans refer to entries; however, these helpful additions are not indexed.

The Frank Lloyd Wright Companion includes extensive illustration credits and a well-formatted directory by zip code, which includes the street address, building name, and Storrer number. Phone numbers for visitor information are listed. The index has entries under client, project (in bold), and geographic name among other access points. With the exception of subject, references are to the Storrer number rather than page number.

This comprehensive reference work lacks a selected bibliography that could add value to what is an indispensable new tool for any Wright collection.K.A.K.

\section{BUSINESS}

Weimerskirch, Arnold, and Stephen George. Total Quality Management: Strategies and Techniques Proven at Today's Most Successful Companies. The Portable MBA series. New York: Wiley, 1994. 286p. \$27.95 (ISBN 0-471-595381). LC $93-24465$.

The guide derives from the performance criteria for the Malcolm Baldridge National Quality Award and presents a model of integrated corporate quality using data from fifty-three leading U.S. 
companies. Initially the book discusses the methodology of a corporate quality model, and outlines how other sections of the book can be used by managers to measure their business elements. Subsequently each of the sixteen major components of the model is discussed in a separate chapter. These are: leadership, customer focus, strategic planning, management, training, reward and recognition, employee focus, customer contacts, design of products and services, process management, supplier quality, data collection and analysis, benchmarking, corporate responsibility and citizenship, and system assessments. For each of these elements a group of companies (being a subset of the fifty-three) is identified whose performance and practices exemplify superior quality and the nature of their success is analyzed.

The work is a useful discussion of the strategies and techniques for using total quality management and thus will be of use to all levels of the workplace.-J.C.

\section{POLITICAL SCIENCE}

Eigen, Lewis D., and Jonathan P. Siegel. The Macmillan Dictionary of Political Quotations. New York: Macmillan, [1993]. 785p. \$40 (ISBN 0-02610650-7). LC 91-40116.

This quotation dictionary is intended to be "a practical tool for the politician, speech writer, journalist, political scientist, historian, student of politics, or anyone interested in politics and its effect on our daily lives"-Pref. The quotations are divided into 99 topics that are arranged in alphabetical order and cover a broad range of current public issues from abortion to welfare. The editors state that these quotations were selected for their "terseness, the character of the speaker or writer, the use of instructive or unusual analogies and metaphors, the persuasive impact of the quotation, the clear statement of an important principle, the classic framing of issues, controversy, humor, surprise, historical parallels, institutional insight, irony, emotion, and inspiration."

The quotations come from both historical and contemporary sources and, although predominantly Anglo-American, international sources. The origins are extremely varied: from the Old Testament and Cicero to very recent political speeches quoted in newspapers, broadcast interviews, bumper stickers, and campaign slogans. Each entry lists speaker, birth and death dates and positions held, source and date of the publication or broadcast, if applicable. All types of historical and contemporary political figures appear-congress people and monarchs, consumer advocates and capitalists.

The volume is indexed by author and "concept." The latter helps to locate appropriate quotations that appear under other topical headings. The book is not only fun to browse but easy to use when looking for an appropriate quotation. An intelligent topical division and the usable subject index help to locate relevant quotations easily.-J.S.

The Oxford Companion to Politics of the World. Ed.-in-chief, Joel Krieger. New York: Oxford Univ. Pr., [1993]. 1,056p. il. maps. \$59.50 (ISBN 0-19-5059344). LC 92-25043.

Shafritz, Jay M., Phil Williams, and Ronald S. Calinger. The Dictionary of Twentieth Century World Politics. New York: Henry Holt, [1993]. 756p. il. \$60 (ISBN 0-8050-1976-6).

The Oxford Companion aims to provide "a comprehensive guide to international relations and national domestic politics through the world" and to a great extent it achieves its goal in a concise one-volume format. It focuses on the "more enduring themes and issues: the social bases of politics; the organizations and institutions of politics at the international and national levels; law, foreign policy, and economic and social policy; the linkage between international and domestic developments; and the recurring patterns of change in diverse societies...."-Pref.

Over 500 scholars (see the list, pp. xiiixxxi), largely from American and British universities, have contributed 650 signed articles with bibliographies. Articles fall into ten categories: (1) short es- 
says on countries, (2) biographies of leaders and intellectual figures, (3) concepts (sovereignty, citizenship, political violence, postindustrial society), (4) conventions, treaties, and developments in international law, (5) forms of government and institutions, (6) historical events, (7) international issues (AIDS, anti-Semitism, liberation theology), (8) international organizations (the Roman Catholic Church, EC, OPEC), (9) domestic political, economic, and social issues, and (10) twenty-one interpretive essays that provide "major analytic treatments of particularly significant and far-reaching themes, such as ethnicity, nationalism, gender and politics, development and underdevelopment, war, democracy, class and politics, political parties and environmentalism." The majority of articles concern the period since World War II. Many of the articles have useful maps.

Following a brief description of its geography, population, and historical background, each of the articles on countries treats the social bases of politics, the political system, socioeconomic policies, internal conflict, and its foreign policy and international relations.

There are some minor, inevitable flaws such as typographical errors (punitive kinship should certainly read putative), but generally, this is a solidly constructed, professional work that should be a valuable reference book for all living in this revolutionary world. The volume ends with a good, general index.

The Dictionary of 20th Century World Politics, by Jay M. Shafritz et al., offers 4,000 entries and covers some of the same material. Its aim is to be a dictionary of "people, theories and ideas that have impacted and transformed international politics in the twentieth century ... specifically including political terms found in newspapers and mass-market journals that have not yet found their way into the text of reference and scholarly books"-Pref. Thus it has many more biographical entries and political events, including international conferences, but with briefer treatment. Useful will be the summaries of treaty provisions. The volume also features "irresist- ible asides" which might be lists of rulers or Nobel Peace Prize winners, a chronology such as the Soviet invasion of Afghanistan, a text such as the Austro-Hungarian declaration of war in 1914 or a quotation or speech. The index is a "key concept" list of broad subjects with a list of relevant articles. There is no bibliography.

The Shafritz volume will be used for ready reference, and identification, while the Oxford Companion will be available for much more extended use.-J.S.

\section{SOCIAL ISSUES}

The Blackwell Dictionary of Twentieth-Century Social Thought. Ed. William Outhwaite and Tom Bottomore. Oxford and Cambridge, Mass.: Blackwell, 1993. 864p. \$49.95 (ISBN 0-631-15262-8). LC 92-20837.

This dictionary covers the vast area of social sciences, philosophy, political science, cultural history, and even natural sciences to the extent that they have influenced social thought. It aims to cover this enormous interdisciplinary field through three key elements: (1) major concepts, (2) principal schools and movements, and (3) institutions and organizations that are important either as the sources of ideas or the subjects of study.

A collaborative endeavor of many contributors (see the list, pp. vii-xiii), the work treats those key ideas and institutions in concise articles that range from half a column to several pages in length. Each article is signed and accompanied by a bibliography of two to ten items for further reading. The articles are arranged alphabetically by topic and followed by the Biographical Appendix (pp. 727-40), which includes major theorists from Adorno to Wittgenstein, and a substantial bibliography of works that have contributed to the shaping of twentieth-century social thought (pp. 741836). The volume ends with a detailed index.-J.S.

Nordquist, Joan. Radical Ecological Theory: A Bibliography. Social Theory: A BibliographicSeries, no.30.SantaCruz, Calif.: 
Reference and Research Services, 1993. 72p. \$15 (ISBN 0-937855-59-6).

This power-packed little bibliography should, like its predecessors in the series, prove useful in any academic library, both for students new to the field as well as for those more advanced needing a quick summary of the topic. It begins with a brief overview of the field and then lists books and articles on such emerging topics as Marxist and socialist ecological theory and ecofeminist theory.

This series, Social Theory, and its companion, Contemporary Social Issues, are intended to provide references to topics and individuals that are currently of interest to college students, from Michel Foucault, for example, to homelessness. They have been very useful in our library when students are overwhelmed by the amount of material keyword searches produce in current periodical indexes. And their commendable habit of citing works by foreign authors in both the original language and English translation has answered many verification questions. These series give relevance a good name.-M.C.

\section{HISTORY}

DeWitt, Donald L. Guides to Archives and Manuscript Collections in the United States: An Annotated Bibliography. Bibliographies and indexes in library and information science, 8. Westport, Conn.: Greenwood, 1994. 478p. (ISBN 0-313-28499-7). LC 93-37179.

The compiler is to be commended for the sheer volume of published archival guides that constitutes this reference book. There are 2,062 entries, ranging from guides to an individual manuscript or archival collection, to repository guides, to national archival guides. Reviewers will no doubt find their own pet omissionsmine is Russia in the Twentieth Century: The Catalog of the Bakhmeteff Archive of Russian and East European History and Culture. Rare Book and Manuscript Library, Columbia University (1DC197).

Any arrangement for such a disparate pool of entries would have had its shortcomings. The compiler chose a topical approach and arranged the entries un- der the following headings: General Collections, Business Collections, Ethnic Minorities and Women, Federal Archives, Fine Arts Collections, Literary Collections, Military Collections, Political Collections, Professional Groups and Organizations, Regional Collections, Religious Groups, Foreign Repositories Holding U.S. Related Records, and U.S. Repositories Holding Foreign Records or Manuscripts.

Not all the headings work equally well. The section under "Federal Archives" devoted to the National Archives, for example, works quite well because one finds there a listing of the published guides to the holdings of the National Archives. However, a subject category such as "Social Science" under the heading "Professional Groups and Organizations" is too imprecise to be meaningful. Its sixteen entries do not begin to do justice to this vast area.

The index-name and subject-helps remedy some of the drawbacks inherent in the arrangement, but it is neither thorough nor precise enough to help locate all the pertinent information on a topic contained in the work. For example, though the annotations often enumerate subjects covered in the collection or repository, these subjects are often not reflected in the index. A case in point: the annotation describing the guide to the Princeton's manuscript collections (\#1,113) mentions renaissance manuscripts, but the index entry for "Renaissance Manuscripts" omits any reference to Princeton. Moreover, entries such as the archival guides of the Center for Migration Studies (\#329) or the guide to the archives of the Scalabrianian Fathers (\#1,766), which deals exclusively with the Italian immigrant experience, are not listed in the index under "Italian American Collections."

This bibliography is a most worthy undertaking. Subsequent editions will surely add entries, and will no doubt improve on the arrangement and index.-O.d.C.

Encyclopedia of the Confederacy. Ed.-inchief, Richard N. Current. New York: Simon \& Schuster, 1993. 4 vols. 
(1,916p.) il. maps. \$295 (ISBN 0-13275991-8). LC 93-4133.

This encyclopedia is "directed not only to professional historians and history students but to everyone who ever has occasion to answer a question about the South during the period of 1861 to $1865^{\prime \prime}$-Pref. It is well-illustrated with many period photographs and etchings, together with modern maps of battles and campaigns. The list of contributors includes such noted historians as Anne Firor Scott, who wrote the entry on women; Elizabeth Fox-Genovese, who contributed the entries on Diaries, Letters, and Memoirs; and Women's Education and Augusta Jane Evans. Other contributors are based in colleges and universities throughout the United States (although predominantly in the South) as well as national battlefields and historic sites, historical societies, museums, libraries, and archives. Signed entries range in length from several paragraphs to more than twenty pages, and from biographical entries to discussions of topics related to union and disunion, government and politics, the military, the economy, and society and culture. All entries include up-to-date bibliographies of secondary materials. This work includes a synoptic outline of contents; nine appendices listing major documents (including the Declaration of the Immediate Cause of Secession, the Constitution, and the various surrender paroles); a subject index; and lists of contributors. Much of the factual information provided could probably be found elsewhere in a major reference collection, but the combination of clear and concise writing, compelling illustrations, and up-to-date bibliographies will make this a welcome addition to reference departments of all sizes.-S.S.

Magosci, Paul Robert. Historical Atlas of East Central Europe. History of East Central Europe, 1. Seattle: Univ. of Washington Pr., 1993. 192p. il. maps. $\$ 75$ (ISBN 0-295-97248-3). LC 9313783.

Students of Eastern Europe will be pleased by word of the release of a new volume in the University of Washington's excellent History of East Central Europe, this one a historical atlas of the region by Paul Magosci, a scholar whose many reference publications include a historical atlas of Ukraine as well. The work fills a gap in the literature admirably, with clear, professionally produced maps documenting the history of the region extending roughly from the "eastern linguistic frontier of Germanand Italian-speaking peoples on the west [to] the political boundaries of Russia/the former USSR in the east." - Foreword. Comprehensive coverage is provided for the Poles, Czechs, Slovaks, Hungarians, Romanians, the Yugoslav peoples, Albanians, Bulgarians, and Greeks from the fifth century through 1992, with more selective treatment of neighboring groups included during various periods, particularly PolandLithuania or Austria-Hungary.

Fullest coverage is given to the everchanging, widely shifting political boundaries and political units of the region, but other maps, particularly in the sections dealing with the nineteenth and twentieth centuries, document geographic regions, demography and migration, ethnolinguistic distribution, military history, ecclesiastical organization, industrial development, and cultural institutions. An extensive commentary provides a detailed outline history of the region and often provides useful statistical and other supplementary data. A clear list of the sources consulted for each map and a more extensive bibliography are included at the end, along with an index of place names.

Naturally, as might be expected in the case of any work this ambitious, there are points over which one might quibble. There is, for example, the consistent, anachronistic use of contemporary national spellings for city names, frequently without any indication of the historic form, which can be quite jarring - to say nothing of misinformative-in the case, say of medieval "Kaliningrad" (rather than "Königsberg"), a diocese of Ermland with its seat at "Frombork" (rather than "Frauenburg"), or the use of the 
Belarusian spelling "Mohilau" for a town almost never so designated in the historical sources and far better known to Western readers as "Mogilev," "Moghilev," or "Mohilev." Also disappointing, for this reader, were the explicit decisions to exclude the territory of contemporary Latvia and Estonia, whose history was very much part of East Central Europe's and, even more, the unspoken decision to leave out, in most cases, the easternmost and northernmost borders of Poland-Lithuania in the fifteenth through seventeenth centuries. Such considerations, however, are of little consequence compared with the great contribution of such a publication to the literature. It is a work that belongs in every collection that claims to document European history, providing as it does, in a compact, accessible form, coverage of a key region whose complex history is far too little known even by educated readers in this country.-R.H.S.

Phillips, Gillian, and Claude Morin. Canada's Relations with Latin America and the Caribbean, 1970-1990: A Bibliography/ Les relations du Canada avec l'Amérique latine et les caraïbes, 19701990. [Ottawa]: Canadian Association of Latin American and Caribbean Studies, [1993]. 1,172 p. (ISBN 0-96972120).

First, why the terrible paper which will become very brittle quickly? One can hope that this means that the compilers plan frequent updates that will supersede the present edition.

The bibliography is based on the collections at the University of Montreal and the Canada-Latin America Resource Center in Toronto, supplemented by materials in about 30 additional libraries and information centers in Ontario and Quebec. It includes citations for over 13,000 books, documents, journal and newspaper articles, and theses in a topical arrangement under the name of a country. For example, Argentina is divided into such headings as Argentinians in Canada, Economy-Debt, Foreign Aid, Human Rights, etc. The documents and articles cited in the French half of the bibliog- raphy could be unique and not translated and so would not appear in the English portion. Access could be improved if the table of contents were more detailed.

The appendix features a list of countries and regions included in the bibliography, acronyms used, periodicals and journals indexed, libraries contacted and databases searched, Canadian organizations and agencies involved with Latin America and the Caribbean with addresses, abbreviations, and codes used in the bibliography.-E.M.

\section{NEW EDITIONS AND SUPPLEMENTS}

The Eighteenth Century Short Title Cata$\log$ (ESTC) is an online union catalog on RLIN providing records of publications printed from 1701 to 1800 in Great Britain or its colonies (including the United States), as well as of English-language publications printed during that period in any part of the world (for a longer description see 1AA128). In April some 75,000 records of materials published from 1473 to 1700 were added, necessitating a change in name to the English Short Title Catalog. The Center for Bibliographic Studies and Research at the University of California at Riverside in conjunction with the British Library will continue to add records until RLIN's coverage of pre-1701 imprints is complete. The records also offer pointers to UMI's microfilm collections, Early English Books, based on the bibliographies of Pollard \& Redgrave (AA802, 1AA127) and Wing (AA819, 1AA131). Already items not in these two printed STCS have been identified. Also beneficial are the enhanced searching techniques available on a computerized database, for example, full titles for keyword searching, as well as provision of locations and shelfmarks.

With the 10th edition, Webster's New Collegiate Dictionary changed names to mirror the new name of the publisher: Merriam-Webster's Collegiate Dictionary (Springfield, Mass.: [1993]. 1,559p. \$20.95; 9 th ed. [1983]. 1563p. AD16). The 10th edition addresses our "ever expanding vocabulary ... [for] words and senses are 
born at a far greater rate than that at which they die out"-Pref. There are a great many new pictorial illustrations and citations. Much revised are the usage paragraphs that are based on the Webster's Dictionary of English Usage ([1989]. 989p. 1AD30). A first-rate desk dictionary.

While preparing for the Third Edition of the Oxford English Dictionary new information is accumulating that the editors, John Simpson and Edmund S. C. Weiner, are now publishing under the title Oxford English Dictionary Additions (vols. 1-2. Oxford: Clarendon Pr.; New York: Oxford Univ. Pr., 1993. \$35 each volume). These initial volumes address English throughout the world and offer new headwords, new senses, collocations, phrases. Thus we have such words as unix, virus (as in computer virus), El Niño. Vol. 2 has a cumulative index to both volumes.

The Australian Dictionary of Biography has thus far covered 1788-1850, 1851$1890,1891-1939$ in 12 volumes with a general index ([1966-[1991]. AJ115, 1AJ33). Volume 13, just published (Melbourne: Univ. Pr., 1993. 362p. \$52), begins a new series for 1940-1980, A-De, with 670 entries; it will be in four volumes and will portray 2,700 lives when it is complete. Volume 13 has a list of corrections identified since the index was published. The Dictionary of Canadian Biography (AJ143), in contrast, publishes individual volumes covering ten years. The latest to appear is v. XIII (Toronto: Univ. Pr., 1994.1295p.), which covers 648 individuals who died 19011910 , written by 438 scholars.

Slovenski biografski leksikon (Ljubljana: Založila Zadružna gos. banka) is now complete with the receipt of fascicles 12 15 for volume 4 and the index, Osebno kazalo (1991. 245p.). Begun in 1925 (AJ399, 1AJ103) the set has long scholarly articles on noted Slovenians. The name index uses boldface type to indicate major entries. With volume 3, Hrvatski biografski leksikon (Zagreb: Jugoslavenski leksikografski zavod, 1993. 1AJ102) has reached C-D for noted Croatians.

When complete, Literatur zur deutschsprächigen Presse: Eine Bibliographie com- piled by Gert Hagelweide (Munich: Saur, 1985-1989. 3 vols. 1AE37) will cover the German-speaking press, mostly of Central Europe up to 1970 . Volume 4 (1993. ÖS2496.) treats the topics: Tageszeitung (Presse), Die Zeitschrift, Almanache und Kalender, Die Presse (Tageszeitung) in Geschichte und Gegenwart (arranged by area). The bibliography is slated to be in nine volumes, the last to be an index volume.

Several periodical and newspaper indexes have changed their pattern of publication. With the 1993 issues, the Alternative Press Index (Baltimore: Alternative Press Center. AE240) is publishing quarterly with the fourth issue being the cumulation for the year. Zeitungs Index (Pullach bei München: Verlag Dokumentation. AF92) is now monthly instead of quarterly. The 1993 issues indexes 21 German newspapers including two from Zurich, one from Vienna, and one from the former East Berlin.

The Index of Jewish Periodicals (Cleveland. BB577) has filled in the gaps with the two annual retrospective indexes for 1988 (published in 1992) and 1989 (published in 1993). The latest index issued covers 1993. It now seems to be an annual.

Offering retrospective indexing is $\mathrm{An}$ tisemitism: An Annotated Bibliography, edited by Susan Sarah Cohen and sponsored by the Vidal Sassoon International Center for the Study of Anti-Semitism, Hebrew University of Jerusalem (New York: Garland. 1BB128). The latest volume received is volume three indexing publications of 1987-88 and published in 1994 (584p. \$85). The Bibliographie zum Antisemitismus/Bibliography of Antisemitism is complete with volume 4 , the Sachregister, compiled by Antje Gerlach (Munich: Saur, 1993. 1,576p.).

Charles Cutter and Micha Falk Oppenheim revised their Judaica Reference Guide (2d ed. Juneau, Alaska: Denali Pr. [1993]. 224p. \$35; 1st ed. 1983. BB539), increasing the number of citations from 371 to 888 annotated entries. Concentrating particularly on works published after 1975, the bibliography relies on Bibliography of Jewish Bibliographies by Shlomo Shunami (1969. BB565) and its 
supplement (1975) for most earlier materials.

The Encyclopedia of World Literature in the 20th Century, Steven R. Serafin and Walter D. Glanze, eds., issued a volume 5: Supplement and Index (New York: Continuum, [1993]. 732p. \$150; vols. 1-4, 1984. BD60). This supplement is intended to "complement the four-volume Revised Edition by providing enlarged treatment of significant literary writers active during the century and throughout the world ... by focusing on the last decade."-Pref. There are continuations of surveys of national literatures and discussions of new literary trends or movements. The index covers all of the five-volume set and thus the previously published index in 1984 is superseded; omitted from the index in volume 5 is boldface type to indicate major topics.

James L. Harner, in his Literary Research Guide: A Guide to Reference Sources for the Study of Literature in English and Related Topics (2d ed. New York: Modern Language Association of America, 1993. 766p. \$45, paper \$19.75; 1st ed. 1989. 1BD149), has revised about half of the entries, deleted superseded works or defunct journals, and added important new reference tools. It now includes " 1,194 entries, refers to an additional 1,248 books and articles in annotations and headnotes and cites 745 reviews." Pref. The guide also includes discussion of technology, for example, union catalog databases online.

Part 4, 1800-1900, of the Index of English Literary Manuscripts has reached Walter Savage Landor, George Meredith, William Morris, Walter Pater, and Coventry Patmore with volume 3 edited by Barbara Rosenbaum ([London]: Mansell, [1993]. 860p. \$500. BD546, 1BD215).

The Literary Criticism Index is also in a new edition (Metuchen, N.J.: Scarecrow, 1994. 580p. \$62.50). Compiled by Alan R. Weiner and Spencer Means the volume now indexes some 147 bibliographies and checklists of criticism, up from 86 in the first edition (1984. 685p. BD119).

The Cambridge Guide to Literature in English, edited by Ian Ousby (New York:
Cambridge Univ. Pr., 1994. 1,054p. il. $\$ 49.95$ ) was formerly published in 1983 as the Cambridge Guide to English Literature (992p. BD554) and again under the present title in 1988 (1,109p. 1BD218). This new edition is considerably revised and expanded with special attention toward increasing the number of American and Commonwealth authors. All of the entries have been read by its editors to update, expand, or shorten the entries as necessary.

The new edition of Mainstream Companion to Scottish Literature, compiled by Trevor Royle (Edinburgh: Mainstream, [1993]. 335p.; formerly Macmillan Companion to Scottish Literature, 1983. BD739) updates the earlier work by concentrating on new writers or movements of the 1980 s. Also, former entries have been revised when needed and additions made. The bibliographies at the ends of the articles have also been made more current. Unfortunately the dictionary is still not indexed, though there are crossreferences.

Scholars working in nineteenth-century French literature have been gifted with the lacking volumes of the Critical Bibliography of French Literature: The Nineteenth Century (Syracuse: Univ Pr., 1994. 2 vols. 1,488 p. $\$ 225$; for volumes published earlier see BD957). The editor, David Baguley, follows the same format as the previously published volumesthat is, scholars assigned chapters on individual authors or genres. The cutoff date is 1989 , with a few "particularly significant" later titles added. Name and subject indexes are included.

For those interested in the theater several new volumes and editions have appeared. Volumes 15-16 of that labor of love, the Biographical Dictionary of Actors, Actresses, Musicians, Dancers, Managers \& Other Stage Personnel (Carbondale, Ill.: Southern Illinois Univ. Pr., 1993. $\$ 60$ per volume. BG96, 1BG36), compiled by Philip H. Highfill, Jr., Kalman A. Burnim, Edward A. Langhans, complete the encyclopedia. There has been no mention of an index.

Reinhart Meyer's Bibliographia dramatica et dramaticorum (Tübingen: Niemeyer. 
1BD295) lists by author German plays of the eighteenth century. Now Meyer has begun a title index, the first three volumes covering 1700-1716. Abteilung 2, Band 1: Einzeltitel (1700) includes the list of libraries and abbreviations, a bibliography of printed sources, and the title index for 1700 - those with known authors and those with anonymous titles ([1993]. 498p.SFr198); Band 2: Einzeltitel (1701-1708) lists by year those titles with authors followed by anonymous titles ([1993].481p. SFr198) as does volume 3 (1709-1716. 487p. SFr198). The alphabetizing is typical of this type of German reference book, that is, alphabetical by the first keyword in the title. An entry includes editions, collections, and occasionally a cast list or summary.

Contemporary Dramatists, ed. K. A. Berney, now in its fifth edition (London and Detroit:St James Pr., [1993]. 843p. \$85; 4 th ed. 1988. 785p., ed. D. L. Kirkpatrick. 1BD88) has grown to include 450 living dramatists. The editor points out that he has made a special effort to include those writing on very contemporary topics such as AIDS, or "whether it is right to seek revenge for criminal wrongs or to erase the memory of suffering."-Pref.

The second edition of International Dictionary of Films and Filmmakers (Chicago: St James Pr.) is complete with the publication of volumes 4-5. Volume 4, Writers and Production Artists, edited by Samantha Cook ([1993]. 836p. \$115), treats art directors, cinematographers, costume designers, composers, music directors (and arrangers and lyricists), editors, choreographers, stuntmen, special effects and sound technicians, makeup artists and animators. Sixty-two of the 530 entries are new. Volume 5 , also edited by Samantha Cook, is the Title Index ([1994]. 421p. \$65) to all the films mentioned in volumes 1-4 with cross-references for alternative or English-language titles.

The Filmlexicon degli autori e delle opere (1958-1974. 9 vols. BG239) is an authoritative, international film encyclopedia. The publishers have now issued an update for the Italian cinema: Sezione Italia: aggiornamenti e integrazioni 19721991 (Roma: Nuova ERI, 1992. 1,092 columns. 81,700 lire). New figures are added and articles from the earlier volumes are extended with reference to the earliercoverage.

William Safire, in his new edition of Safire's New Political Dictionary: The Definitive Guide to the New Language of Politics (New York: Random House, [1993]. 930p. \$35), points out that since the third edition was published in 1978 (CJ99), he has seen the "advent of three new administrations, the end of the Cold War, the dissolution of Soviet-type communism."-Introd. His fourth edition reflects these changes and, as always, is fun to browse.

Kenneth Martis has compiled a number of very helpful atlases for the study of United States politics, for example Historical Atlas of U.S. Congressional Districts, 1789-1983 (1982. CJ154); Historical Atlas of Political Party Representation in the U.S. Congress 1789-1989 (1988. 1CJ116). His newest one, compiled with Gregory A. Elmes, the Historical Atlas of State Power in Congress 1789-1990 (Washington, D.C.: Congressional Quarterly [1993]. 190p. $\$ 56.9527 \mathrm{~cm}$.), covers Congressional apportionment by decade and geographically through colored maps, tables and charts, and explanatory text. Some of the material is taken from the Historical Atlas of U.S. Congressional Districts, 1789-1983.

Scarecrow Press has been publishing the Native American Bibliography Series since 1980 (1CC218). The newest addition is The Seneca and Tuscarora Indians: An Annotated Bibliography, by Marilyn Haas (1994.450p. \$55). This is an exhaustive undertaking listing books, chapters and essays, pamphlets, journal articles, theses, ERIC documents, fiction and nonfiction for children, state and federal documents, and "tribally focused periodicals" (Introd.) for 1791-1992, mostly in English. The arrangement is by broad subjects with author/editor and subject indexes. Since the Seneca and the Tuscarora were part of the Iroquois nation, the bibliography cites a number of larger works on the Iroquois.

Another series concerning the Native American is the Handbook of the American Frontier: Four Centuries of Indian-White 
Relationships written by J. Norman Heard ((Metuchen: Scarecrow). It is a dictionary of short articles on the tribes and the explorers, missionaries, tribal leaders, traders, settlers, battles, treaties, etc. who had contacts with each other. Volume 1 discussed The Southeastern Woodlands (1987. 421p.) and volume 2 provided the same coverage for The Northeastern Woodlands (1990. 414p.) Now volume 3, The Great Plains (1993. [265]p. \$32.50), continues the coverage. The set is to be in five volumes with the general index, bibliography, and chronology in the final volume.

Francis Paul Prucha compiled an extremely useful Handbook for Research in American History (1987. 1DB1). In his second revised edition (Lincoln, Nebr: Univ. Nebraska Pr., [1994]. 214p. \$25; $\$ 9.95$ paper) the first part for essays and bibliographies of types and formats of reference books is much expanded and rewritten to incorporate the new technologies (the Internet, CD-ROMs, etc.). Part 2 of the first edition, which covered topical bibliographies (e.g., women, social history, chronological periods), has been dropped and some of the citations incorporated into some of the remaining sections. Still a major guide for American historians.

The Bibliography of European Economic and Social History is in a second edition, compiled by Derek Aldcroft and Richard Rodger (Manchester: Univ. Pr., distributed by St. Martin's Pr., New York, [1993]. 292p. \$69.95; 1st ed. 1984. DC10). The bibliography covers the period 1700 to 1939 with about 9,000 entries; this is an increase of about 3,000 mostly from the 1980 s. Similar to the first edition, the volume is arranged topically under the names of the countries, for example, urban history, social structure and social conditions, industry and internal trade. There is an author index.

"To conform to the new realities brought about by the demise of the Soviet Union" (p. ii), the editors have changed the title of the Modern Encyclopedia of Russian and Soviet History to the Modern Encyclopedia of Russian, Soviet and Eurasian History. The first volume with the new title is volume 56 (1994)-an Index of Countries and Authors. Part 1 is an alphabetical list of entries including the Supplement with See References included; part 2 is an alphabetical list of authors in all the volumes with a list of all their articles under each entry.

J. M. Dent, London, has published a number of Martin Gilbert's atlases in new editions, still in black-and-white, and most with little or no commentary. The Dent Atlas of American History, (3d ed. 1993 . 138 p. $£ 14.99$. $27 \mathrm{~cm}$.; 1 st ed. 1968; rev. ed. 1985) has grown to 138 maps with the 26 new ones bringing the atlas up to date, for example, new ethnic and population changes, including growth of the immigrant population, natural and accidental disasters, death rates, the U.S. overseas. It is instructive to learn what a non-American sees as important.

Dent Atlas of Jewish History (5th ed. [1993]. [136]p. £14.99. 26cm.; formerly called Jewish History Atlas, 1st ed. 1969. DA65) has been revised despite a 1992 edition (issued in the U.S. in 1993): a number of new maps (e.g., anti-Semitic incidents in Europe 1992, Hebrew language classes in the former Soviet Union 1992); updated maps (e.g., immigration of Jews to Israel, non-Jews honored for saving lives in World War II); and newly added material (e.g., blood libel accusations in the Middle Ages, scale of Jewish resistance in the Holocaust). The bibliography, though, is current only up to about 1986.

The Dent Atlas of the Holocaust (2d ed. [1993]. 282p. 25cm. £14.99; 1st ed. 1982; reprinted, 1988. 1DA85) increased the coverage to 316 photographs, maps, lists with explanatory text, and expanded the index to include individuals and more places. The bibliography, pp. 246-53, indicates the map number beside the relevant source title.

The Official ABMS Directory of Board Certified Medical Specialists must be a cataloger's nightmare. The 26th ed., 1994 though published in 1993 (New Providence, N.J.: Marquis Who's Who, 1993. 4 vols. 8,377 p. $\$ 390$ ), was formed by the merger of the Directory of Medical 
Specialists (EK132) and the Official American Board of Medical Specialities Directory of Board Certified Medical Specialists (formerly called the ABMS Compendium of Certified Medical Specialists). These two titles had an earlier merger in 1985. This new directory lists 428,000 practicing and retired physicians within 24 specialties boards. Also included in the volume are lists of accredited medical schools, state licensing boards, approved specialty boards, general information on each board, and tables of requirements and certification data.

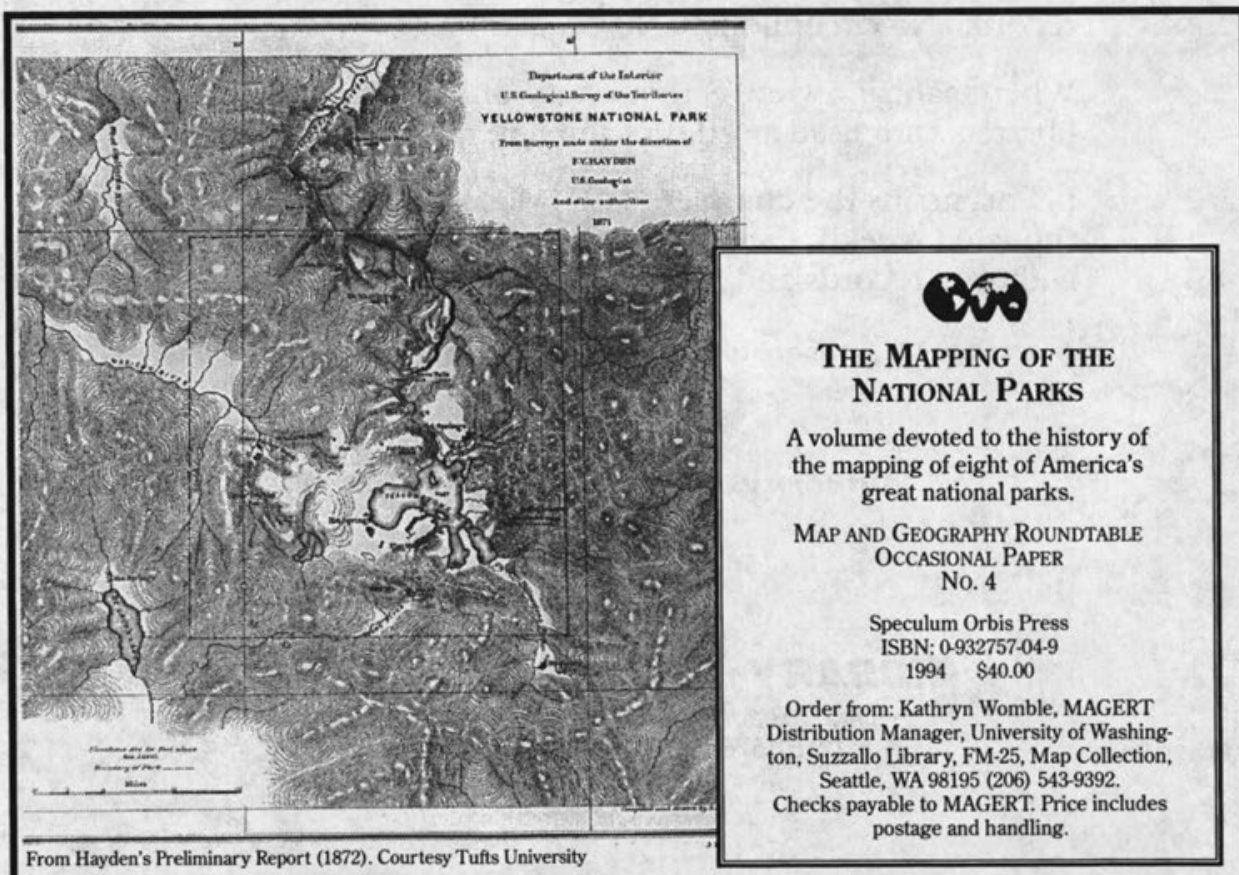




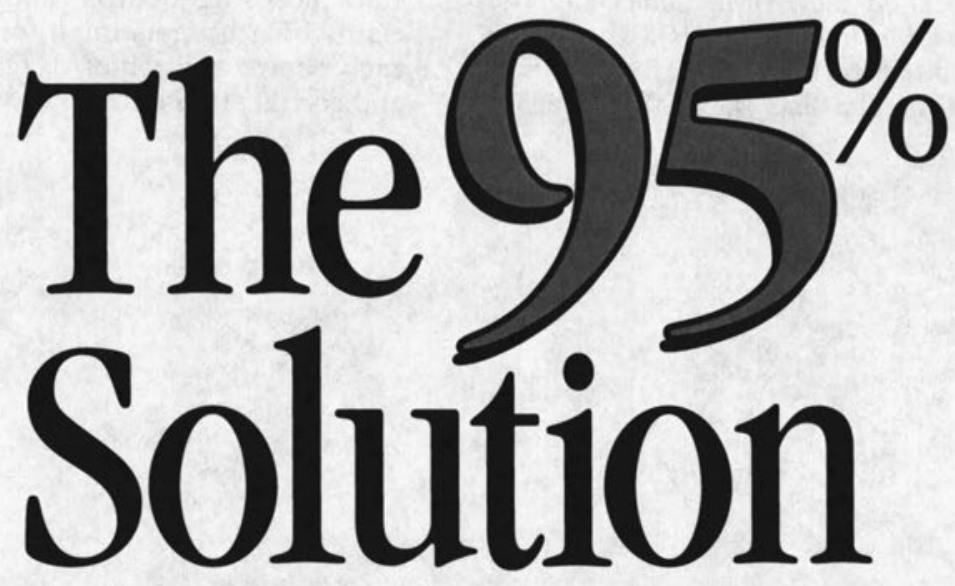

You get one chance with authority control, so it's important to get it done right. LTI guarantees that its affordable, machine-only authority control will link $95 \%$ or more of your library's controlled headings to an LC or LTI authority record. No exceptions! No excuses!

When manual review is requested, only professional librarians are used as editors and link rates approach $100 \%$.

LTI maintains the complete LC MARC authority files (updated weekly), supplemented with over 410,000 LTI authority records and 350,000 proprietary "cross links."

Contact LTI for more information on authority record link results.

"Authority Control for the 21st Century"

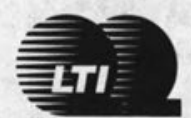

LIBRARY TECHNOLOGIES, INC.

1142E Bradfield Road Abington, PA 19001

(215) 576-6983 Fax: (215) 576-0137

(800) $795-9504$ 